\title{
Recent patent applications in breast cancer diagnostics
}

\begin{tabular}{|c|c|c|c|c|c|}
\hline Patent number & Description & Assignee & Inventor & $\begin{array}{l}\text { Priority } \\
\text { application } \\
\text { date }\end{array}$ & $\begin{array}{c}\text { Publication } \\
\text { date }\end{array}$ \\
\hline WO 2011083090 & $\begin{array}{l}\text { A method of treating breast cancer selected } \\
\text { from primary breast cancer, metastatic } \\
\text { breast cancer, inflammatory breast cancer or } \\
\text { medullary carcinoma, involving administering } \\
\text { to patient a composition comprising an } \\
\text { antibody that specifically binds to progastrin. }\end{array}$ & $\begin{array}{l}\text { Centre National de la Recherche } \\
\text { Scientifique (Paris), Institut } \\
\text { National de la Santé et de la } \\
\text { Recherche Médicale (Paris), } \\
\text { BioRéalités (Montpellier, France) }\end{array}$ & $\begin{array}{l}\text { Cailler F, Floch J, } \\
\text { Hollande F, } \\
\text { Houhou L, } \\
\text { Joubert D }\end{array}$ & $1 / 8 / 2010$ & $7 / 14 / 2011$ \\
\hline JP 2011137685 & $\begin{array}{l}\text { A method of detecting breast cancer involving } \\
\text { measuring the quantity of cathepsin } \mathrm{E} \text { in a test } \\
\text { sample, where the measurement result is related } \\
\text { to diagnosis or prognosis of breast cancer. }\end{array}$ & $\begin{array}{l}\text { Nagoya University (Nagoya, Japan), } \\
\text { Kyushu University (Fukuoka, Japan), } \\
\text { Saitama University } \\
\text { (Saitama, Japan) }\end{array}$ & $\begin{array}{l}\text { Kawakubo T, } \\
\text { Nishigaki K, } \\
\text { Yamamoto K, } \\
\text { Yamashita K }\end{array}$ & $12 / 28 / 2009$ & $7 / 14 / 2011$ \\
\hline WO 2011081421 & $\begin{array}{l}\text { A composition useful for diagnosing cancer, } \\
\text { e.g., lung cancer, breast cancer, renal cancer } \\
\text { and uterine cancer, comprising an agent } \\
\text { capable of measuring the expression level of } \\
\text { complement C9 mRNA or protein encoded by } \\
\text { mRNA. }\end{array}$ & $\begin{array}{l}\text { Kyungpook National University } \\
\text { Industry-Academic Cooperation } \\
\text { Foundation (Daegu, S. Korea) }\end{array}$ & Cho JY & $12 / 28 / 2009$ & $7 / 7 / 2011$ \\
\hline WO 2011080373 & $\begin{array}{l}\text { An in vitro method for predicting the response } \\
\text { of a subject diagnosed with breast cancer to } \\
\text { treatment with chemotherapy with a taxane } \\
\text { and an antimetabolite, an intercalating agent } \\
\text { and a DNA alkylating agent, comprising } \\
\text { determining gene expression levels in a test } \\
\text { tumor tissue sample. }\end{array}$ & $\begin{array}{l}\text { Centro de Investigaciones } \\
\text { Energéticas, Medioambientales } \\
\text { y Tecnológicas (Madrid) }\end{array}$ & $\begin{array}{l}\text { Garcia Escudero R, } \\
\text { Paramio Gonzalez } \\
\text { JM }\end{array}$ & $12 / 31 / 2009$ & 7/7/2011 \\
\hline WO 2011081164 & $\begin{array}{l}\text { A new humanized antibody useful in a } \\
\text { pharmaceutical composition for preventing } \\
\text { and/or treating immunoglobulin A nephropathy } \\
\text { and cancer, e.g., plasmacytoma, breast cancer, } \\
\text { uterine cancer and colon cancer. }\end{array}$ & $\begin{array}{l}\text { Kyowa Hakko Kirin Co. Ltd. } \\
\text { (Tokyo) }\end{array}$ & Kubota T & 12/29/2009 & $7 / 7 / 2011$ \\
\hline $\begin{array}{l}\text { US } 20110130302 \text {, } \\
\text { WO } 20110688410\end{array}$ & $\begin{array}{l}\text { A method for determining a drug-response } \\
\text { profile of a breast tumor specimen or cell } \\
\text { culture derived from tumor specimen, by } \\
\text { extracting RNA for the breast tumor specimen } \\
\text { and determining the expression level of genes } \\
\text { associated with enriched pathways in drug- } \\
\text { sensitive or drug-resistant cells to prepare the } \\
\text { drug response profile. }\end{array}$ & $\begin{array}{l}\text { Precision Therapeutics } \\
\text { (Pittsburgh, PA, USA) }\end{array}$ & $\begin{array}{l}\text { Brower SL, Ding Z, } \\
\text { Ervin PR, Gabrin M, } \\
\text { Gingrich DA, } \\
\text { Rice SD, Shen K, } \\
\text { Song N, Tian C, } \\
\text { Wang D }\end{array}$ & $12 / 1 / 2009$ & $\begin{array}{l}6 / 2 / 2011 \\
6 / 9 / 2011\end{array}$ \\
\hline WO 2011066263 & $\begin{array}{l}\text { A new anthraquinone compound useful } \\
\text { for treating cancer, e.g., breast cancer, } \\
\text { glioblastoma and pancreatic cancer, and } \\
\text { for inhibiting tumor cell migration and } \\
\text { proliferation in a tumor cell-containing } \\
\text { medium. }\end{array}$ & $\begin{array}{l}\text { Ohio State University } \\
\text { (Columbus, OH, USA) }\end{array}$ & Li C, Li P, Lin J & $11 / 24 / 2009$ & $6 / 3 / 2011$ \\
\hline US 20110123441 & $\begin{array}{l}\text { A new isolated antibody that specifically binds } \\
\text { to a gene regulated by estrogen in breast } \\
\text { cancer } 1 \text { proteins, polypeptides, peptides, } \\
\text { nucleic acids, mutants, variants or isoforms } \\
\text { in vitro or in vivo; useful for, e.g., treating } \\
\text { cancer and imaging. }\end{array}$ & $\begin{array}{l}\text { University of Michigan } \\
\text { (Ann Arbor, MI, USA), } \\
\text { University of Miami } \\
\text { (Miami, FL, USA) }\end{array}$ & $\begin{array}{l}\text { Hnatyszyn HJ, } \\
\text { Lippman ME, } \\
\text { Liu M, Rae JM }\end{array}$ & 10/23/2009 & $5 / 26 / 2011$ \\
\hline $\begin{array}{l}\text { EP 2322619, } \\
\text { WO } 2011061194\end{array}$ & $\begin{array}{l}\text { A new compound for modulating the function } \\
\text { of a specific target gene in a cell and for } \\
\text { treating/preventing cancer, e.g., acute myeloid } \\
\text { leukemia, adrenocortical carcinoma, bladder } \\
\text { cancer, brain stem glioma, breast cancer and } \\
\text { carcinoid tumor. }\end{array}$ & $\begin{array}{l}\text { Deutsches Krebsforschungszentrum } \\
\text { (Heidelberg, Germany) }\end{array}$ & $\begin{array}{l}\text { Boutros M, } \\
\text { Fuchs F, } \\
\text { Kraemer A, } \\
\text { Leber B, Maier B }\end{array}$ & $11 / 17 / 2009$ & $\begin{array}{l}5 / 18 / 2011 \\
5 / 26 / 2011\end{array}$ \\
\hline CN 102041259 & $\begin{array}{l}\text { An isolated DNA molecule encoding } \\
\text { human G protein-coupled receptor } 116 \\
\text { (GPR116) protein, selected from a defined } \\
\text { nucleotide sequence of } 5,822 \text { bp given in } \\
\text { the specification; useful for diagnosing and } \\
\text { treating breast cancer. }\end{array}$ & $\begin{array}{l}\text { East China Normal University } \\
\text { (Shanghai) }\end{array}$ & $\begin{array}{l}\text { Jin R, Liu M, } \\
\text { Luo J, } \\
\text { Tang X, } \\
\text { Wang X }\end{array}$ & 10/12/2009 & $5 / 4 / 2011$ \\
\hline CN 102041302 & $\begin{array}{l}\text { Use of Ner-like protein gene in preparing an } \\
\text { agent for diagnosing breast and lung cancer } \\
\text { of mammals (preferably human), a method of } \\
\text { preparing a composition to treat breast and } \\
\text { lung cancer of mammals, and producing breast } \\
\text { and lung cancer animal models. }\end{array}$ & $\begin{array}{l}\text { Tumour Research Institute, Chinese } \\
\text { Academy of Medical Sciences } \\
\text { (Beijing) }\end{array}$ & $\begin{array}{l}\text { Jia L, Liu R, } \\
\text { Shao S, Song Y, } \\
\text { Wang Y, Zhan Q }\end{array}$ & $10 / 16 / 2009$ & $5 / 4 / 2011$ \\
\hline
\end{tabular}

Source: Thomson Scientific Search Service. The status of each application is slightly different from country to country. For further details, contact Thomson Scientific, 1800 Diagonal Road, Suite 250, Alexandria, Virginia 22314, USA. Tel: 1 (800) 337-9368 (http://www.thomson.com/scientific). 